\title{
Convergent (De)Hydrogenative Pathways via a Rhodium $\alpha$-Hydroxylalkyl Complex
}

\author{
Simon Sung, ${ }^{\dagger}$ Jie Kang Boon, ${ }^{\dagger}$ Johnathan J. C. Lee, ${ }^{\dagger}$ Nasir A. Rajabi, ${ }^{\ddagger}$ Stuart A. Macgregor, ${ }^{\ddagger}$ \\ Tobias Krämer, ${ }^{+*} *(1)$ and Rowan D. Young ${ }^{\dagger} *(1)$
}

${ }^{\dagger}$ Department of Chemistry, National University of Singapore, 3 Science Drive 3, 117543 Singapore

${ }^{\ddagger}$ Institute of Chemical Sciences, Heriot-Watt University, Edinburgh EH14 4AS, United Kingdom

\section{Supporting Information}

ABSTRACT: We report the convergent reaction pathways between $\left[\mathrm{RhH}\left(\mathrm{PPh}_{3}\right)_{4}\right]$ and POP ketone (1) and alcohol (2) ligands that terminate in the formation of an $\alpha$-hydroxylalkyl rhodium(I) complex (3), representing two halves of a formal reduction/oxidation pathway between 1 and 2 . In the case of hydride transfer to $\mathbf{1}$, the formation of the $\alpha$-hydroxylalkyl rhodium(I) complex (3) proceeds via a rare hydrido $\left(\eta^{2}\right.$ carbonyl) complex (4). C-H activation in 2 at the proligand's central methine position, rather than $\mathrm{O}-\mathrm{H}$ activation of the hydroxy motif, followed by loss of dihydrogen also generates the $\alpha$-hydroxylalkyl rhodium(I) complex (3). The validity of the postulated reaction pathways is probed with DFT calculations. The observed reactivity supports $\alpha$-hydroxylalkyl complexes as competent intermediates in ketone hydrogenation catalyzed by rhodium hydrides and suggest that ligands $\mathbf{1}$ and $\mathbf{2}$ may be "noninnocent" coligands in reported hydrogenation catalyst systems in which they are utilized.

\section{INTRODUCTION}

The transfer of hydrogen from metals to ketones and, through reversibility, from alcohols to metals is of fundamental importance to (de)hydrogenation reactions mediated by metal catalysts. ${ }^{1}$ Such reactions involve metal hydride intermediates and can proceed via two distinct pathways involving hydride transfer to either the electrophilic carbon or the nucleophilic oxygen of the carbonyl group (Scheme 1).

Scheme 1. Ketone Hydrogenation Proceeding via an Alkoxide Intermediate (Route A) or an $\alpha$-Hydroxylalkyl Intermediate (Route B)

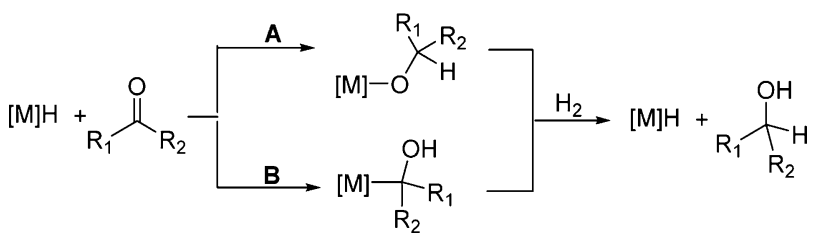

Thus, basic metal monohydrides tend to form metal alkoxide intermediates with ketones (Scheme 1 , route $\mathbf{A}$ ); $\mathrm{H}_{2}$ addition then gives the alcohol product and regenerates the metal hydride. ${ }^{2,3}$ In contrast, hydrogenation of aldehydes and ketones with acidic metal hydrides has been observed to proceed via $\alpha$ hydroxylalkyl intermediates in acidic media (Scheme 1 , route B). ${ }^{4}$

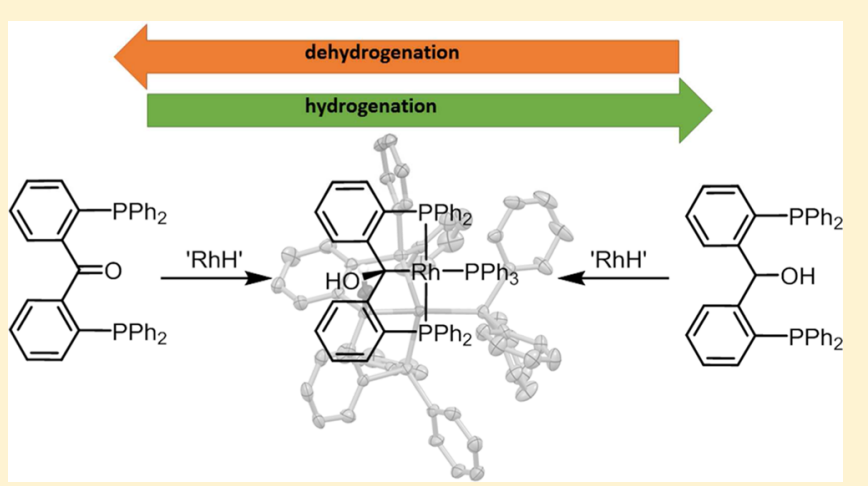


Scheme 2. Formation of 3 from Addition of 1 or 2 to $\left[\mathrm{RhH}\left(\mathrm{PPh}_{3}\right)_{4}\right]^{a}$

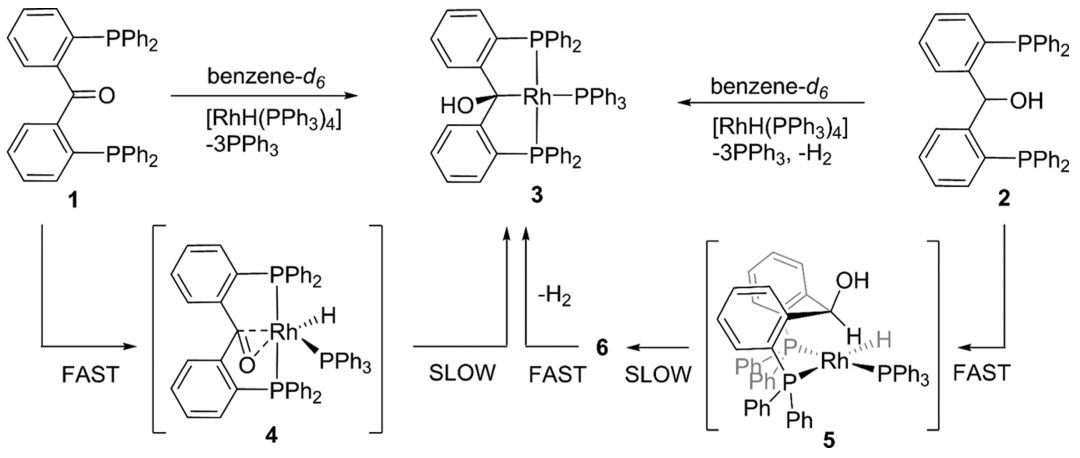

${ }^{a}$ Geometry of compound 6 is discussed below.

the single-step $\mathrm{C}-\mathrm{H}$ activation and functionalization of alcohol geminal $\mathrm{C}-\mathrm{H}$ positions remaining a contemporary chemical challenge. ${ }^{8}$ However, such selective $\mathrm{C}-\mathrm{H}$ activation is unknown, so this approach is nontrivial due to the presence of several alternative reaction outcomes.

Herein we describe the controlled hydrogen transfer to and from the ketone and alcohol moieties of the diphosphine POP ligands $\mathbf{1}^{9}$ and $\mathbf{2}^{10}$ mediated by hydridotetrakis(triphenylphosphine)rhodium(I), $\left[\mathrm{RhH}\left(\mathrm{PPh}_{3}\right)_{4}\right]$. The results demonstrate a convergent pathway to a common $\alpha$ hydroxylalkyl complex that is accessible from both ketone and alcohol precursors using a common ligand platform. Within this we demonstrate the formation of an $\alpha$-hydroxylalkyl species direct from a rare isolated metal-hydride $/ \eta^{2}$-ketone precursor, as well as the geminal $\mathrm{C}-\mathrm{H}$ activation of an alcohol. DFT calculations are utilized to probe the mechanistic details of these processes which are shown to map out fully route B shown in Scheme 1. The results also highlight the potential noninnocence of these POP ligands, which are commonly used in asymmetric hydrogenation catalysis. ${ }^{9}$

\section{RESULTS AND DISCUSSION}

Addition of POP ketone 1 to $\left[\mathrm{RhH}\left(\mathrm{PPh}_{3}\right)_{4}\right]$ in benzene- $d_{6}$ resulted in the loss of 3 equiv of $\mathrm{PPh}_{3}$ and the formation of the $\alpha$-hydroxyl complex 3 over $12 \mathrm{~h}$. Monitoring the reaction at shorter time intervals revealed that $\mathbf{1}$ and $\left[\mathrm{RhH}\left(\mathrm{PPh}_{3}\right)_{4}\right]$ initially formed hydrido $\left(\eta^{2}\right.$-carbonyl) 4 (within minutes) that was converted into 3 over a matter of hours at room temperature (Scheme 2). Formation of 4 was evident by the presence of a rhodium-bound carbon $\left(\delta_{\mathrm{C}} 137.8,{ }^{1} J_{\mathrm{RhC}}=9.2\right.$ $\mathrm{Hz}$ ). The chemical shift and rhodium-carbon coupling constant deviate notably from that of the proligand carbonyl $\left(\delta_{\mathrm{C}}\right.$ 197.3) and imply a bonding mode lying between the extreme cases of $\eta^{2}$-carbonyl and metallaepoxide (defined by the Dewar-Chatt-Duncanson model) and exemplified by recently reported analogues $\left[1-\mathrm{Ni}\left(\mathrm{PPh}_{3}\right)\right]^{11}$ and $\left[\mathrm{L}_{1} \mathrm{IrX}\right]^{12}\left(\mathrm{~L}_{1}\right.$ $=\kappa^{3}-P,\left(\eta^{2}-\mathrm{C}, \mathrm{O}\right), P^{\prime}$-bis (5-(diisopropylphosphino)3,4-benzo $[b]$ thiophenyl)-methanone, $\mathrm{X}=\mathrm{Cl}$ or $\mathrm{OH})$. A degree of $\pi$ retrodonation to the carbonyl is supported by relatively small one-bond rhodium-phosphorus coupling constants $\left({ }^{1} J_{\mathrm{RhP}}=\right.$ 130.6, $108.9 \mathrm{~Hz}$ ) in 4 indicating an electron-poor rhodium center. FTIR spectroscopy could not provide support for carbonyl coordination with failure to identify a specific $\mathrm{C}=\mathrm{O}$ stretching band. However, a strong $\mathrm{Rh}-\mathrm{H}$ stretch was observed at $1969 \mathrm{~cm}^{-1}$ (cf. calcd value of $1993 \mathrm{~cm}^{-1}$, see Supporting Information).
Crystals of compound 4 were grown upon layering a toluene solution of 4 with hexane at low temperature $(253 \mathrm{~K})$. The molecular structure of 4 (Figure 1) supports the coordination

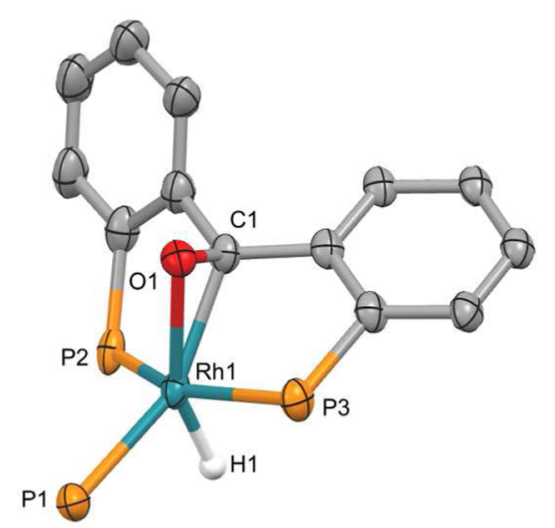

Figure 1. Molecular structure of 4. Phenyl groups and hydrogens except $\mathrm{H} 1$ are omitted for clarity; 50\% thermal ellipsoids. H1 was located in a Fourier difference map. Selected distances $(\AA)$ and angles (deg): Rh1-C1, 2.118(7); Rh1-O1, 2.187(5); Rh1-P1, 2.382(2); Rh1-P2, 2.318(2); Rh1-P3, 2.262(2); C1-O1, 1.339(8); P2-Rh1P3, 153.19(8); P1-Rh1-C1, P1, 152.3(2).

of the carbonyl to rhodium, observed spectroscopically in solution. The geometry around rhodium is best described as pseudotrigonal bipyramidal, with numerous examples of analogous pentacoordinate rhodium complexes subtended by $\eta^{2}$-olefin ligands exhibiting such geometry. ${ }^{13}$ Significant elongation of the $\mathrm{C}=\mathrm{O}$ bond $(1.339(8) \AA)$ from the free ligand $1(1.213(3) \AA)^{9}$ is observed indicating a significant degree of $\pi$-retrodonation. However, the coordination is consistent with a bound carbonyl, falling within the range of previously reported rhodium $\eta^{2}$-carbonyl complexes. ${ }^{14}$ Notably, the molecular structure of $\mathbf{4}$ reveals the hydrido ligand to be trans to the oxygen in the coordinated carbonyl, representing a barrier for hydride to carbonyl migration.

In solution, $\alpha$-hydroxylalkyl complex 3 is generated from 4 upon the transfer of hydrogen from rhodium to oxygen. The ${ }^{1} \mathrm{H}$ NMR spectrum of compound 3 exhibits a hydroxyl resonance at $3.15 \mathrm{ppm}\left({ }^{4} J_{\mathrm{PH}}=3.5 \mathrm{~Hz}\right)$. Selective decoupling of a phosphorus signal at $\delta_{\mathrm{P}} 37.5$ resolves the signal at $\delta_{\mathrm{H}} 3.15$ into a singlet, indicative of long-range ${ }^{1} \mathrm{H}-{ }^{31} \mathrm{P}$ coupling. The addition of $\mathrm{D}_{2} \mathrm{O}$ to a solution of 3 resulted in the disappearance of this signal, while other NMR signals remained unaffected. The carbon-rhodium bond in $\mathbf{3}$ is characterized by a doublet 
of doublet of triplets signal in the ${ }^{13} \mathrm{C} \mathrm{NMR}$ spectrum at $\delta_{\mathrm{C}}$ $106.1\left({ }^{1} J_{\mathrm{RhC}}=25.2 \mathrm{~Hz}\right)$, with a typical ${ }^{1} J_{\mathrm{RhC}}$ for a rhodium $\alpha$ hydroxylalkyl moiety. ${ }^{7 \mathrm{~b}, \mathrm{~h}, \mathrm{i}}$

$\mathrm{X}$-ray diffraction study confirms 3 to be an $\alpha$-hydroxylalkyl complex (Figure 2). In agreement with solution data, 3 assumes

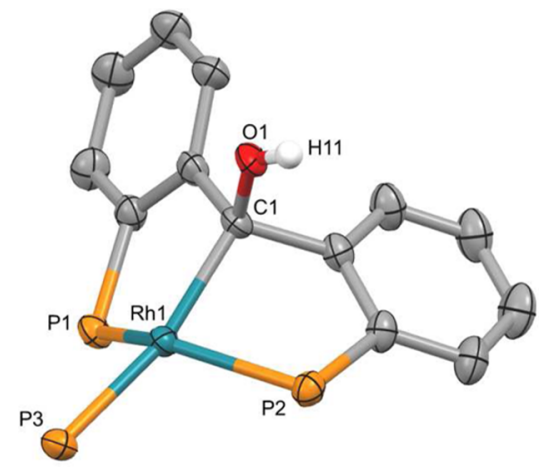

Figure 2. Molecular structure of 3. Phenyl groups, benzene solvent molecule, and hydrogens except $\mathrm{H} 11$ are omitted for clarity; 50\% thermal ellipsoids. H11 was located in a Fourier difference map. Selected distances $(\AA)$ and angles (deg): Rh1-C1, 2.103(12); C1O1, 1.458(14); Rh1-P1, 2.231(3); Rh1-P2, 2.254(3); Rh1-P3, 2.315(3); P1-Rh1-P2, 132.45(13); P3-Rh1-C1, 166.4(4); O1C1-Rh1, 106.4(8).

a distorted square-planar geometry, with $\mathrm{P} 1-\mathrm{Rh} 1-\mathrm{P} 2$ and $\mathrm{C} 1-$ Rh1-P3 angles deviating greatly from linear (132.45(13) and $166.4(4)^{\circ}$, respectively). The significantly reduced average $\mathrm{Rh}-$ $\mathrm{P}$ bond distances in 3 as compared to those in 4 point to a more electron-rich $\mathrm{Rh}$ center in the former. The formation of 3 from 4 was monitored with ${ }^{1} \mathrm{H}$ and ${ }^{31} \mathrm{P}$ NMR spectroscopy across a range of temperatures and in the presence of varying quantities of added $\mathrm{PPh}_{3}$ (see Supporting Information). Although it was apparent that free $\mathrm{PPh}_{3}$ accelerated the reaction, the exact reaction order relative to $\left[\mathrm{PPh}_{3}\right]$ could not be precisely determined, but it was found to be between 0 and 1. This may be indicative of a nontrivial mechanism. Thus, although accurate activation parameters from these collected data could not be derived, they are discussed in the Supporting Information.

Compound 3 could also be generated by the addition of alcohol proligand 2 to $\left[\mathrm{RhH}\left(\mathrm{PPh}_{3}\right)_{4}\right]$ in benzene- $d_{6}$ with concomitant loss of $\mathrm{H}_{2}$ (Scheme 2). The formation of $\mathbf{3}$ from $\mathbf{2}$ and $\left[\mathrm{RhH}\left(\mathrm{PPh}_{3}\right)_{4}\right]$ completes the (de)hydrogenation reaction pathway between 1 and 2 mediated by $\left[\mathrm{RhH}\left(\mathrm{PPh}_{3}\right)_{4}\right]$. Monitoring the production of 3 from the combination of either 1 or 2 with $\left[\mathrm{RhH}\left(\mathrm{PPh}_{3}\right)_{4}\right]$ reveals that once a maximum concentration of $\mathbf{3}$ has been achieved very small quantities of 4 are still observed. In the presence of $>1$ equiv of $\mathrm{PPh}_{3}$, this equilibrium is established in a matter of days but takes weeks to establish in the absence of $\mathrm{PPh}_{3}$. The ratio of $3 / 4$ after equilibrium is established is ca. 20:1 (see Supporting Information), suggesting a $\Delta G$ of $-1.8 \mathrm{kcal} \mathrm{mol}^{-1}$.

En route to compound 3 from 2 and $\left[\mathrm{RhH}\left(\mathrm{PPh}_{3}\right)_{4}\right]$, compound $\mathbf{5}$ is observed. Although $\mathbf{5}$ is transient at room temperature, at $280 \mathrm{~K}$ it can be spectroscopically characterized and is distinguished by the appearance of new signals in the ${ }^{1} \mathrm{H}$ NMR spectrum at $\delta_{\mathrm{H}} 9.87(\mathrm{br} \mathrm{s})$ and $1.39\left(\mathrm{~d},{ }^{3} \mathrm{~J}_{\mathrm{HH}}=3.3 \mathrm{~Hz}\right)$ that correlate to one another in a COSY 2D NMR experiment. A HSQC experiment provided no correlation for the signal at $\delta_{\mathrm{H}} 1.39$ to any ${ }^{13} \mathrm{C}$ atoms but rather correlated the signal at $\delta_{\mathrm{H}}$
9.87 with a signal at $\delta_{\mathrm{C}} 69.3$. These data suggest the identities of the signals at $\delta_{\mathrm{H}} 9.87$ and 1.39 to be the methine $\mathrm{CH}$ and $\mathrm{OH}$ signals of bound 2 respectively. In the upfield region of the ${ }^{1} \mathrm{H}$ NMR spectrum of 5 , a broad doublet is observed at $\delta_{\mathrm{H}}-8.58$ $\left({ }^{2} J_{\mathrm{PH}}=90 \mathrm{~Hz}\right), 0.52 \mathrm{ppm}$ upfield of the hydride signal of $\left[\mathrm{RhH}\left(\mathrm{PPh}_{3}\right)_{4}\right]\left(\delta_{\mathrm{H}}-8.06,{ }^{1} J_{\mathrm{RhH}}=12.7 \mathrm{~Hz}\right)$, suggesting fluxional behavior. The ${ }^{31} \mathrm{P}$ NMR spectrum of $\mathbf{5}$ further revealed the dynamic behavior of $\mathbf{5}$, with two broad doublets present at $\delta_{\mathrm{P}} 34.3\left({ }^{1} J_{\mathrm{RhP}}=170 \mathrm{~Hz}\right)$ and $31.0\left({ }^{1} J_{\mathrm{RhP}}=131 \mathrm{~Hz}\right)$ with a combined integral of three phosphorus nuclei relative to free $\mathrm{PPh}_{3}$ (integration: 3P).

Analysis by ${ }^{31} \mathrm{P}$ NMR spectroscopy of a solution of $\mathbf{5}$ and liberated $\mathrm{PPh}_{3}$ generated from $\left[\mathrm{RhH}\left(\mathrm{PPh}_{3}\right)_{4}\right]$ and 2 in toluene$d_{8}$ at $223 \mathrm{~K}$ revealed the presence of at least three separate phosphorus environments on rhodium (integration: 4P) with complex coupling patterns in addition to free $\mathrm{PPh}_{3}$ (integration: $2 \mathrm{P}$ ). At this temperature, the ${ }^{1} \mathrm{H}$ spectrum of $\mathbf{5}$ revealed that fluxional processes were still occurring on the ${ }^{1} \mathrm{H}$ NMR time scale. The hydridic signal remained broad. However, it had shifted upfield to $-12.22 \mathrm{ppm}$, and the ${ }^{2} J_{\mathrm{PH}}$ for this signal had increased to $110 \mathrm{~Hz}$. Concurrently, the methine $\mathrm{CH}$ signal in bound 2 had shifted upfield from $\delta_{\mathrm{H}} 9.87$ to 9.20 . Overall, the NMR data imply that 5 exists in equilibrium with its $\mathrm{PPh}_{3}$ adduct, $5 \cdot \mathrm{PPh}_{3}$, and that the adduct may be preferred at lower temperatures.

A downfield shift for $\mathrm{C}-\mathrm{H}$ bonds in the vicinity of $\mathrm{d}^{8}$ metals has been observed in bisphosphino methylene ligands related to 2 (that also undergo $\mathrm{C}-\mathrm{H}$ activation) and has previously been assigned as an anagostic interaction. ${ }^{15}$ Assignment based purely on NMR spectroscopic evidence has recently been reported to be misleading; however, we cautiously assign the $\mathrm{C}-\mathrm{H}-\mathrm{Rh}$ interaction as anagostic with supporting computational analysis (see below). ${ }^{16}$

Further insight into the $\mathrm{C}-\mathrm{H}$ activation of POP alcohol ligand 2 was obtained from its reaction with $[\mathrm{RhCl}(\mathrm{COD})$ $\left.\mathrm{PPh}_{3}\right]$ that led to the formation of the hydridochloride 7 alongside free 1,5-cyclooctadiene (Scheme 3 ). ${ }^{1} \mathrm{H}$ NMR data

Scheme 3. Reaction of 2 and $\left[\mathrm{RhCl}(\mathrm{COD}) \mathrm{PPh}_{3}\right]$ to Form $7^{a}$

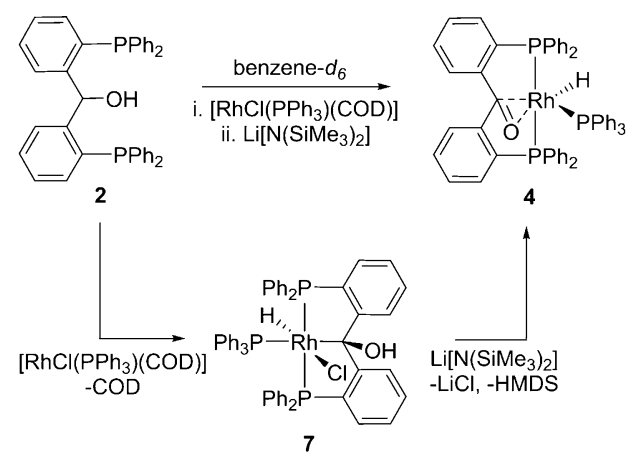

${ }^{a}$ Subsequent treatment of 7 with $\mathrm{Li}\left[\mathrm{N}\left(\mathrm{SiMe}_{3}\right)_{2}\right]$ produces 4 .

support compound 7 being an $\alpha$-hydroxylalkyl complex, with a hydroxyl signal located at $\delta_{\mathrm{H}}$ 7.57. This signal appears as a doublet with long-range coupling to phosphorus $\left(\mathrm{d},{ }^{4} J_{\mathrm{PH}}=7.5\right.$ $\mathrm{Hz}$ ); selective ${ }^{31} \mathrm{P}$ decoupling at $\delta_{\mathrm{P}} 23.7$ collapses this signal to a singlet. The addition of a small quantity of $\mathrm{D}_{2} \mathrm{O}$ also resulted in the disappearance of the signal while other NMR data remain unaffected. The ${ }^{1} \mathrm{H}$ NMR spectrum also reveals the appearance of an upfield hydride shift at $\delta_{\mathrm{H}}-16.22\left(\mathrm{dtd},{ }^{1} J_{\mathrm{RhH}}=22.1 \mathrm{~Hz}\right.$ (d), $\left.{ }^{2} J_{\mathrm{PH}}=14.3 \mathrm{~Hz}(\mathrm{t}),{ }^{2} J_{\mathrm{PH}}=9.2 \mathrm{~Hz}(\mathrm{~d})\right)$. 
A molecular structure determination of 7 (Figure 3) reveals its geometry with the PCP ligand adopting a mer configuration

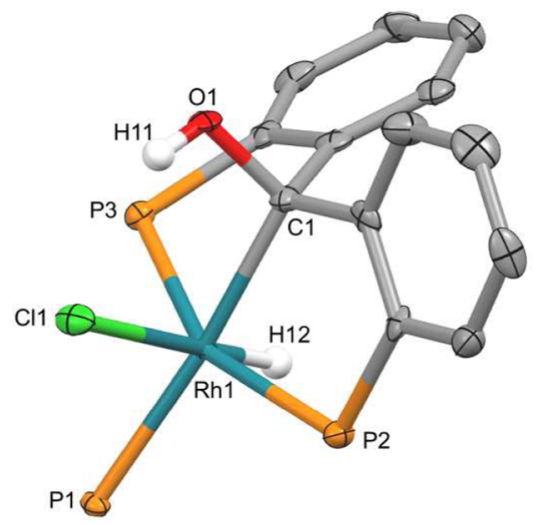

Figure 3. Molecular structure of 7. Phenyl groups and hydrogens except $\mathrm{H} 11$ and $\mathrm{H} 12$ are omitted for clarity; 50\% thermal ellipsoids. $\mathrm{H} 11$ and $\mathrm{H} 12$ were located in a Fourier difference map. Selected distances ( $\AA$ ) and angles (deg): Rh1-C1, 2.177(4); Rh1-Cl1, 2.500(1); Rh1-P1, 2.4019(12); Rh1-P2, 2.3189(13); Rh1-P3, 2.2971(12); P2-Rh1-P3, 153.03(4); P1-Rh1-C1, 174.46(12).

after $\mathrm{C}-\mathrm{H}$ oxidative addition to the rhodium center. It is also observed that the hydroxyl hydrogen (H11), located in a Fourier difference map, is hydrogen-bonded to the proximal chloride ligand $\left(\mathrm{Cl} 1-\mathrm{H} 11_{\text {dist }}=2.273 \AA\right.$ ). Induced elimination of $\mathrm{HCl}$ from 7 by treatment with 1 equiv of $\mathrm{Li}\left[\mathrm{N}\left(\mathrm{SiMe}_{3}\right)_{2}\right]$ results in the formation of compound 4 , which then transforms to 3 . This stands in contrast to the reaction between 2 and $\left[\mathrm{RhH}\left(\mathrm{PPh}_{3}\right)_{4}\right]$ that generates 3 without any observation of $\mathbf{4}$, signifying that $\mathrm{H}_{2}$ loss occurs via a cis-dihydride intermediate rather than through elimination of $\mathrm{H}_{2}$ from a trans-dihydride analogue of 7 (i.e., a trans- $\mathrm{Rh}^{\mathrm{III}}(\mathrm{H})_{2}(\mathrm{COH}) \mathrm{P}_{2}$ fragment).

To investigate the possible identity of cis-dihydride intermediate 6, dihydrogen (4 atm) was introduced into an NMR sample tube containing 3 in toluene- $d_{8}$ solution. At room temperature, ${ }^{1} \mathrm{H}$ NMR spectroscopy reveals the formation of a broad signal at $\delta_{\mathrm{H}}-2.8$ (integration: $2 \mathrm{H}$ ). In addition, the signal for free $\mathrm{H}_{2}$ (expected at $\delta_{\mathrm{H}} 4.50$ ) is not observed. The hydroxyl signal originally at $\delta_{\mathrm{H}} 3.15$ is broadened and observed to shift downfield to $\delta_{\mathrm{H}} 3.65$ (integration: $1 \mathrm{H}$ ). The ${ }^{31} \mathrm{P}$ NMR spectrum of this sample reveals resonances at $\delta_{\mathrm{P}} 45.6(\mathrm{dd}, 2 \mathrm{H}$, $\left.{ }^{1} J_{\mathrm{RhP}}=125.1 \mathrm{~Hz},{ }^{2} J_{\mathrm{PP}}=20.2 \mathrm{~Hz}\right)$ and $41.7\left(\mathrm{dt}, 1 \mathrm{H},{ }^{1} J_{\mathrm{RhP}}=93.2\right.$ $\mathrm{Hz},{ }^{2} J_{\mathrm{PP}}=20.2 \mathrm{~Hz}$ ), displaying a similar chemical shift to 3 , but reduced coupling constants. As the temperature is lowered to $233 \mathrm{~K}$, the hydridic signal resolves into a broad doublet at $\delta_{\mathrm{H}}-$ $6.8\left({ }^{2} J_{\mathrm{PH}}=140 \mathrm{~Hz}\right)$, indicative of a single trans phosphorushydride environment. $\mathrm{T}_{1}$ measurements at various temperatures excluded the identity of $\mathbf{6}$ as a dihydrogen complex (see Supporting Information). At this temperature, the hydroxyl signal is observed at $\delta_{\mathrm{H}} 4.25$ as a doublet $\left({ }^{4} J_{\mathrm{PH}}=4.4 \mathrm{~Hz}\right)$, and free hydrogen is observed as a broad signal at $\delta_{\mathrm{H}} 4.5$ that sharpens at lower temperatures. A ${ }^{1} \mathrm{H}\left\{{ }^{31} \mathrm{P}\right\}$ NMR spectrum with a decoupling window centered at $\delta_{\mathrm{P}} 40.0$ collapses both the hydridic and hydroxyl signals into singlets.

The ${ }^{31} \mathrm{P}$ NMR spectrum of the sample at $233 \mathrm{~K}$ shows a broad doublet at $\delta_{\mathrm{P}} 45.6\left({ }^{1} J_{\mathrm{RhP}}=86.5 \mathrm{~Hz}\right)$ and a doublet of triplets at $\delta_{\mathrm{P}} 41.7\left({ }^{1} J_{\mathrm{RhP}}=84.5 \mathrm{~Hz},{ }^{2} J_{\mathrm{PP}}=14.9 \mathrm{~Hz}\right)$. HMBC experiment at $233 \mathrm{~K}$ (optimized for $J_{\mathrm{CH}}=10 \mathrm{~Hz}$ ) exhibits a correlation between the hydroxyl proton at $\delta_{\mathrm{H}} 4.25$ and a signal at $\delta_{\mathrm{C}} 95.8$. A $1 \mathrm{D}{ }^{13} \mathrm{C}$ NMR experiment revealed this signal to be a doublet of doublets $\left({ }^{2} J_{\mathrm{PC}}=95.2 \mathrm{~Hz},{ }^{1} J_{\mathrm{RhC}}=28.6 \mathrm{~Hz}\right)$. After warming and degassing of the sample, compound 3 was quantitatively reformed. These data are indicative of the formation of a $\mathrm{Rh}(\mathrm{III})$ center at low temperature in dynamic equilibrium with 3 and molecular hydrogen. Given these spectroscopic data, 6 is assigned as a cis dihydride featuring a facially coordinated PCP ligand (Scheme 4$).{ }^{15 b, e}$ Selected NMR spectroscopic data for compound 3-7 are shown in Table 1.

Scheme 4. Hydrogenation of 3 Generates Cis Dihydride 6

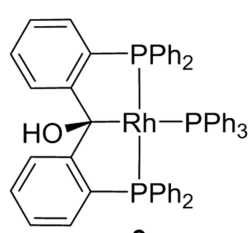

3

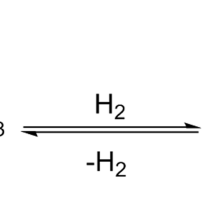

$H_{2}$

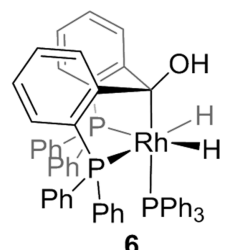

6
Confirmation that the $\mathrm{C}-\mathrm{H}$ methine of $\mathbf{2}$ is activated in reactions with rhodium (as opposed to $\mathrm{O}-\mathrm{H}$ activation followed by rearrangement) is confirmed by employing isotopologues $\mathbf{2 a}$ and $\mathbf{2 b}$ (Scheme 5). $\mathrm{C}-\mathrm{H}$ activation is expected on a dehydrogenation pathway that invokes an $\alpha$ hydroxylalkyl intermediate. When $\left[\mathrm{RhH}\left(\mathrm{PPh}_{3}\right)_{4}\right]$ is reacted with isotopologue $\mathbf{2 a}$, 3a is generated (Scheme 5), which is spectroscopically identical to 3 , except that the $\mathrm{RhCOH}$ signal at $\delta_{\mathrm{H}} 3.15$ was diminished and a signal at $3.25 \mathrm{ppm}$ was located in the ${ }^{2} \mathrm{H}$ NMR spectrum of $3 \mathrm{a}$, signifying the deuteration of the hydroxyl position. Conversely, when $\mathbf{2 b}$ is reacted with $\left[\mathrm{RhH}\left(\mathrm{PPh}_{3}\right)_{4}\right]$, compound 3 is produced with loss of $\mathrm{HD}$. Addition of $\mathbf{2} \mathbf{b}$ to $\left[\mathrm{RhCl}(\mathrm{COD}) \mathrm{PPh}_{3}\right]$ resulted in the production of $7 \mathbf{b}$, identical to 7 (by NMR spectroscopy) with the exception of substitution of the hydride ligand with deuterium, as evident by the absence of a hydridic signal in the ${ }^{1} \mathrm{H}$ NMR spectrum.

To elucidate the mechanistic details of the convergent pathways that convert both the ketone (4) and alcohol (5) precursors into the $\alpha$-hydroxylalkyl product 3, a computational analysis of the associated free energy surfaces was carried out using DFT calculations at the B97-D3/BS2//BP86/BS1 level of theory corrected for benzene solvent (see Supporting Information for computational details). The most accessible computed pathways at $298 \mathrm{~K}$ for both processes are detailed in Figure 4. The optimized structure of $\mathbf{4}$ agrees well with the crystallographic data. In particular the $\mathrm{C}=\mathrm{O}$ (calcd: $1.35 \AA$, exp.: $1.339(8) \AA$ ), $\mathrm{Rh}-\mathrm{C}$ (calcd: $2.16 \AA$, exp.: $2.118(7) \AA$ ), and Rh-O (calcd: $2.22 \AA$, exp.: $2.187(5) \AA$ ) distances are wellreproduced, along with the trans- $\mathrm{P}-\mathrm{Rh}-\mathrm{P}$ angle of the POP ligand (calcd: $154.0^{\circ}$, exp.: $153.19(8)^{\circ}$ ).

Analysis of the natural bond orbitals (NBOs) in 4 shows that $\mathrm{C}=\mathrm{O}$ coordination to the metal center is governed by $\pi_{\mathrm{CO}} \rightarrow$ $\mathrm{Rh}$ donation, reinforced by substantial $\pi^{*} \mathrm{CO} \leftarrow \mathrm{Rh}$ backdonation (see Figure S65). The elongation of the $\mathrm{C}=\mathrm{O}$ bond arises due to notable population of the $\pi^{*}{ }_{\mathrm{CO}}$ orbital $\left(0.79 \mathrm{e}^{-}\right)$ and depopulation of the $\pi_{\mathrm{CO}}$ orbital $\left(1.82 \mathrm{e}^{-}\right)$. The partial reduction of the double-bond character of the $\mathrm{C}=\mathrm{O}$ bond is also reflected in the Wiberg bond index (1.18), lying in between those for the $\mathrm{C}=\mathrm{O}$ double bond in $\mathbf{1}$ (1.68) and the $\mathrm{C}-\mathrm{O}(\mathrm{H})$ single bond in $2(0.91)$. In contrast, the indices for the $\mathrm{Rh} \cdots \mathrm{C}(0.39)$ and $\mathrm{Rh} \cdots \mathrm{O}(0.24)$ interactions are smaller compared to those found for the $\mathrm{Rh}-\mathrm{C}(0.47)$ and $\mathrm{Rh}-\mathrm{H}$ $(0.56)$ bonds in 3 and 4 , respectively, which serve as a reference 
Table 1. Selected NMR Spectroscopic Data for Compounds 3-7

\begin{tabular}{|c|c|c|c|c|c|}
\hline compound & $\delta_{\mathrm{C}}(\mathrm{Rh}-\mathrm{C})$ & ${ }^{2} J_{\mathrm{PC}}(\mathrm{Hz})$ & ${ }^{1} J_{\mathrm{RhC}}(\mathrm{Hz})$ & $J_{\mathrm{RhP}}(\mathrm{Hz})$ & $J_{\mathrm{PP}}(\mathrm{Hz})$ \\
\hline 3 & 106.1 & $4.8(\mathrm{t}), 73.5(\mathrm{~d})$ & 25.2 & 189,120 & 28.3 \\
\hline 4 & 137.8 & $23.7(\mathrm{~d})^{a}$ & 9.2 & 131,109 & 10.1 \\
\hline 5 & $\mathrm{~N} / \mathrm{A}$ & $\mathrm{N} / \mathrm{A}$ & $\mathrm{N} / \mathrm{A}$ & $170,131^{b}$ & $a$ \\
\hline 6 & $95.8^{c}$ & $95.2(\mathrm{~d})^{a, c}$ & $28.6^{c}$ & $87,85^{c}$ & $14.9^{c}$ \\
\hline 7 & 99.4 & $94.1(\mathrm{~d})^{a}$ & 20.8 & 120,79 & 24.0 \\
\hline
\end{tabular}

${ }^{a}$ Coupling to cis phosphorus nuclei was not observed. ${ }^{b} 280 \mathrm{~K} .{ }^{c} 233 \mathrm{~K}$.

Scheme 5. Isotopomers $2 \mathrm{a}, 2 \mathrm{~b}$ React with $\left[\mathrm{RhH}\left(\mathrm{PPh}_{3}\right)_{4}\right]$ to Generate Isotopologues $3 a$ and $7 b$, Respectively

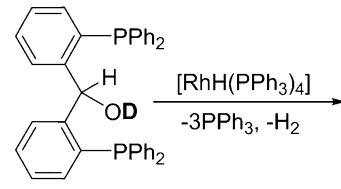

$2 a$

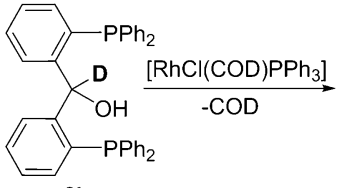

2b

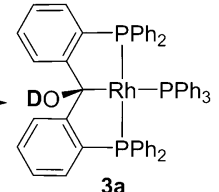

3a

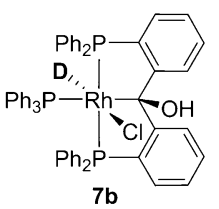

$7 b$ point. Thus, in accordance with the experimental findings the $\{\mathrm{RhCO}\}$ unit is best described as a Rh-bound carbonyl.
The optimized structure of 3 reproduces the distorted square-planar geometry around $\mathrm{Rh}$ seen experimentally: trans$\mathrm{P}-\mathrm{Rh}-\mathrm{P}$ (calcd: $132.9^{\circ}$, exp.: 132.45(13); trans-C-Rh-P (calcd: $164.1^{\circ}$, exp.: $166.4(4)$ ). The $\mathrm{Rh}-\mathrm{C}$ distance is reduced from $2.16 \AA$ in 4 to $2.13 \AA$ in 3 , and this is paralleled by an increase in the calculated $\mathrm{Rh}-\mathrm{C}$ isotropic spin-spin coupling constant $\left(4:{ }^{1} J_{\mathrm{RhC}}=-9.1 \mathrm{~Hz} ; 3:{ }^{1} J_{\mathrm{RhC}}=-17.4 \mathrm{~Hz}\right)$.

The computed mechanism for the formation of 3 from 4 starts with an initial isomerization of 4 , with a calculated barrier of $17.7 \mathrm{kcal} \mathrm{mol}^{-1}$ proceeding via TS(4-Int1). The POP ligand undergoes isomerization from a $m e r-\kappa^{3}-\mathrm{P},(\mathrm{CO}), \mathrm{P}$ to a $f a c-\kappa^{3}-\mathrm{P}$, (CO),P binding mode $\left(\angle \mathrm{P}-\mathrm{Rh}-\mathrm{P} 109.1^{\circ}\right)$. Concomitantly, the hydride moves from its equatorial coordination site trans to oxygen into the opening axial position. The distortion of the ligand in TS(4-Int1) also causes the $\mathrm{C}=\mathrm{O}$ unit to move away from $\mathrm{Rh}(\mathrm{Rh}-\mathrm{O}: 2.52 \AA ; \mathrm{Rh}-\mathrm{C}: 2.38 \AA$ ), thereby decreasing $\pi$ backbonding from the metal center and restoring more double-

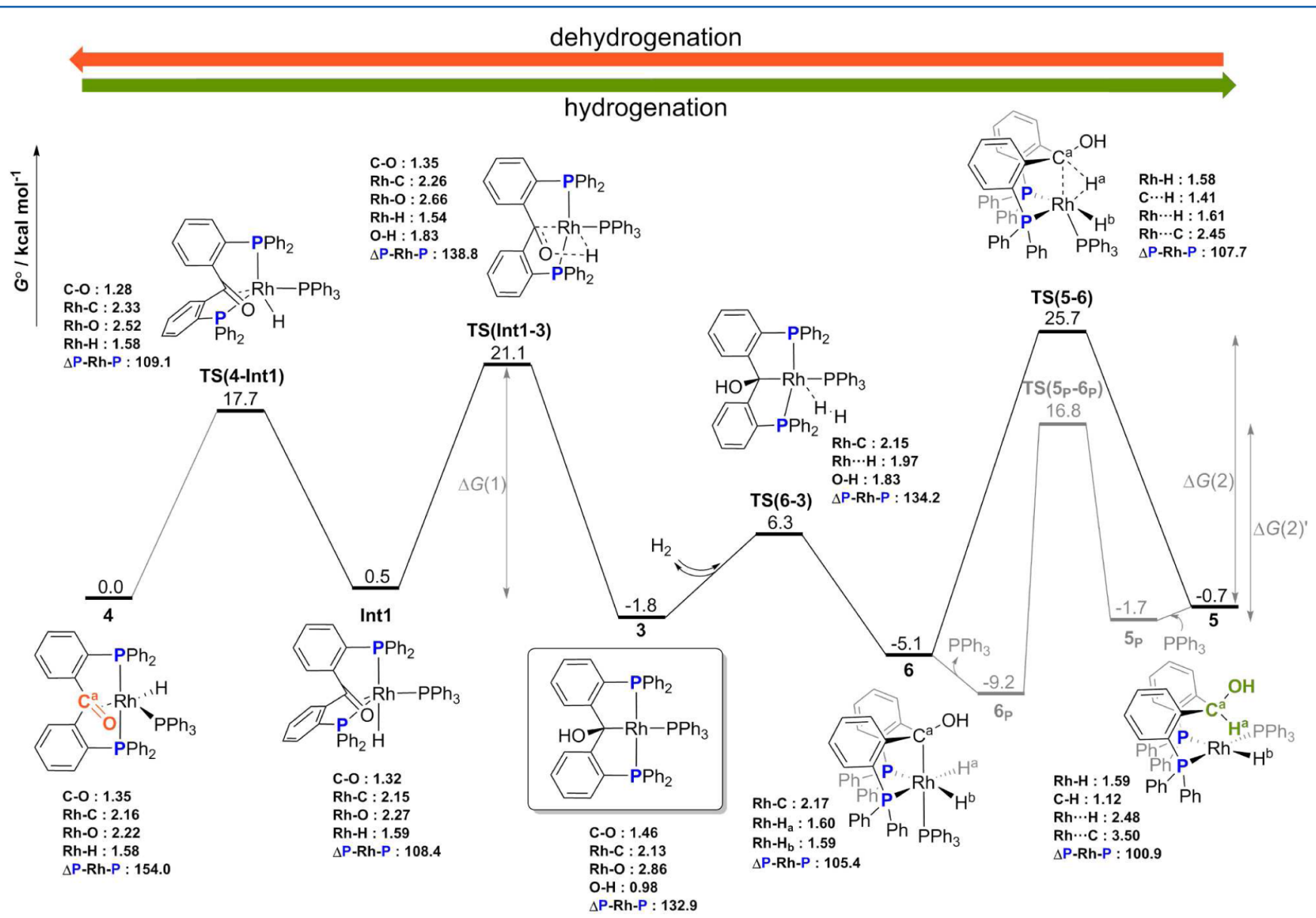

Figure 4. Computed profile (B97-D3/BS2//BP86/BS1) for the transformation of 4 into 3 (left) and $\mathbf{5}$ into 3 (right). The gray profile is associated with adduct $\mathbf{5}_{\mathrm{P}}$, featuring $\mathrm{H}$-bonded $\mathrm{PPh}_{3}$. Relative Gibbs free energies $\left(298 \mathrm{~K}, \mathrm{kcal} \mathrm{mol}^{-1}\right)$, corrected for benzene solvent, are given along with key bond metric data ( $\AA$, deg). Double-arrows indicate energy spans $\Delta G(1), \Delta G(2)$, and $\Delta G(2)^{\prime}$. 
bond character $(\mathrm{C}=\mathrm{O}: 1.28 \AA)$. The cis arrangement of the $\{\mathrm{Rh}(\mathrm{C}=\mathrm{O})(\mathrm{H})\}$ moiety in Int1 $\left(G^{\circ}=+0.5 \mathrm{kcal} \mathrm{mol}^{-1}\right)$ allows for insertion of the ketone into the $\mathrm{Rh}-\mathrm{H}$ bond through TS(Int1-3) at $21.1 \mathrm{kcal} \mathrm{mol}^{-1}$ to form the $\alpha$-hydroxylalkyl in 3. By inspection, TS(Int1-3) also defines the overall energetic $\operatorname{span}^{17}\left(\Delta G(1)=+21.1 \mathrm{kcal} \mathrm{mol}^{-1}\right)$ for the transformation of 4 into 3 , with the computed barrier being consistent with the slow process seen experimentally. The hydrogen transfer in TS(Int1-3) is accompanied by an isomerization of the ligand to its distorted $m e r-\kappa^{3}-\mathrm{P}, \mathrm{C}, \mathrm{P}$ form $\left(\angle \mathrm{P}-\mathrm{Rh}-\mathrm{P} 138.8^{\circ}\right)$. Complex 3 is energetically stabilized by a mere $1.8 \mathrm{kcal}$ $\mathrm{mol}^{-1}$ relative to 4 . The marginal exergonicity of this process is in line with the establishment of an equilibrium between these two species, as confirmed by experiment.

The lowest-energy pathway for the formation of $\mathbf{3}$ from $\mathbf{5}$ is shown on the right side of Figure 4. Precursor complex 5 features an approximately square-planar geometry around the $\mathrm{Rh}^{\mathrm{I}}$ center, with the POP ligand adopting a $c i s-\kappa^{2}-\mathrm{P}, \mathrm{P}$ arrangement $\left(\angle \mathrm{P}-\mathrm{Rh}-\mathrm{P} 100.9^{\circ}\right)$ and computed $\mathrm{Rh} \cdots \mathrm{H}^{\mathrm{a}}$ and $\mathrm{Rh} \cdots \mathrm{C}^{\mathrm{a}}$ distances of 2.48 and $3.50 \AA$, respectively, to the central $\mathrm{C}-\mathrm{H}$ bond of the ligand. Computed AIM and NBO parameters suggest that the $\mathrm{Rh} \cdots \mathrm{H}^{\mathrm{a}}-\mathrm{C}^{\mathrm{a}}$ interaction is of closed-shell electrostatic nature, in line with a weak anagostic interaction. ${ }^{16,18}$ Oxidative addition of the $\mathrm{C}^{\mathrm{a}}-\mathrm{H}^{\mathrm{a}}$ bond across the $\mathrm{P}_{\mathrm{POP}}-\mathrm{Rh}-\mathrm{PPh}_{3}$ vector occurs with a barrier of $26.4 \mathrm{kcal} \mathrm{mol}^{-1}$ to yield intermediate $6\left(-5.1 \mathrm{kcal} \mathrm{mol}^{-1}\right)$. Activation of the C$\mathrm{H}$ bond in TS $(5-6)$ is accompanied by movement of the $\mathrm{PPh}_{3}$ ligand into the axial position. We have also considered other possibilities for this reaction step, none of which presented a feasible alternative. Oxidative addition across the $\mathrm{P}_{\mathrm{PPh} 3}-\mathrm{Rh}-\mathrm{H}$ vector in the alternative trans-isomer $5^{\prime}$ shifts the energy profile upward by $\sim 10 \mathrm{kcal} \mathrm{mol}^{-1}$ (see Supporting Information). A search for a concerted $\mathrm{C}-\mathrm{H}$ activation step via $\sigma$-bond metathesis proved unsuccessful. Experimentally there is an excess of $\mathrm{PPh}_{3}$ present in solution, so we also scrutinized the possible effect of $\mathrm{C}(\mathrm{H}) \mathrm{OH} \cdots \mathrm{PPh}_{3} \mathrm{H}$-bonding on the $\mathrm{C}-\mathrm{H}$ activation. Under these circumstances, the barrier is notably lowered $\left(\Delta G^{\circ \ddagger}=18.5 \mathrm{kcal} \mathrm{mol}^{-1}\right.$, relative to $\boldsymbol{S}_{\mathbf{P}}$, gray profile in Figure 4$)$. The optimized structure of the corresponding transition state $\operatorname{TS}\left(5_{\mathrm{P}}-\mathbf{6}_{\mathrm{P}}\right)$ is shown in Figure 5. The optimized bond parameters in $\mathbf{T S}\left(5_{\mathrm{P}}-\mathbf{6}_{\mathrm{P}}\right)$ closely resemble those in TS(5-6), with $\mathrm{Rh} \cdots \mathrm{C}^{\mathrm{a}}$, Rh $\cdots \mathrm{H}^{\mathrm{a}}$, and $\mathrm{C}^{\mathrm{a}}-\mathrm{H}^{\mathrm{a}}$ distances of 2.45 , 1.61 , and $1.43 \AA$, respectively. The $(\mathrm{O}) \mathrm{H} \cdots \mathrm{PPh}_{3}$ distance is 2.45 $\AA$, similar to the H-bond in complex $\mathbf{5}_{\mathrm{P}}$. Complex $\mathbf{6}$ exhibits an

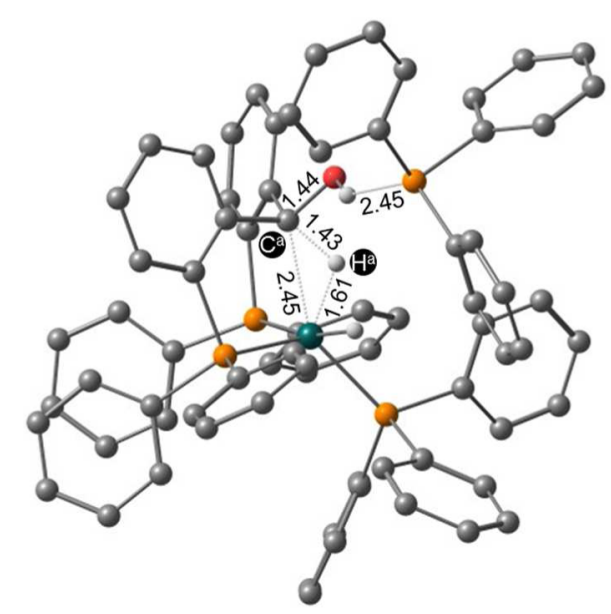

Figure 5. Optimized geometry of $\operatorname{TS}\left(5_{P}-6_{P}\right)$. Bond distances are in $\AA$. octahedral coordination geometry around the $\mathrm{Rh}^{\mathrm{III}}$ center, featuring a $\mathrm{fac}^{3} \mathrm{~K}^{3}-\mathrm{P}, \mathrm{C}, \mathrm{P}$ tridentate ligand with the $\mathrm{Rh}-\mathrm{C}$ bond trans to $\mathrm{PPh}_{3}$. Facile reductive elimination of the cis-hydrides in 6 proceeds with a barrier of $11.4 \mathrm{kcal} \mathrm{mol}^{-1}$ readily generating the final product 3 upon loss of $\mathrm{H}_{2}$. The overall reaction rate is determined by the initial oxidative addition step at $18.5 \mathrm{kcal}$ $\mathrm{mol}^{-1}$, and this reduced barrier is consistent with the observation that $\mathbf{5}$ is transient at room temperature. Note that although the formation of $\mathbf{3}$ is computed to be slightly endergonic relative to $6\left(\Delta G^{\circ}=+3.3 \mathrm{kcal} \mathrm{mol}^{-1}\right)$ experimentally species 3 and $\mathbf{6}$ are in equilibrium which can be driven to 3 by removal of $\mathrm{H}_{2}$ upon degassing the solution.

Experimentally the NMR characterization of $\mathbf{5}$ points to it being fluxional in solution and, moreover, that temperaturedependent coordination of $\mathrm{PPh}_{3}$ to the $\mathrm{Rh}$ center also occurs. Computationally, the trigonal-pyramid and trans- $\kappa^{2}-\mathrm{P}, \mathrm{P}$ isomers of 5 lie $\sim 10 \mathrm{kcal} \mathrm{mol}^{-1}$ above the cis-isomer, so these may be kinetically accessible in potential $\mathrm{H} / \mathrm{PPh}_{3}$ exchange pathways. ${ }^{19}$ Formation of a trigonal-bipyramidal 18-electron complex, 5 . $\mathrm{PPh}_{3}$, via axial addition of $\mathrm{PPh}_{3}$ to 5 was computed to be energetically strongly favored $\left(\Delta G^{\circ}=-7.6 \mathrm{kcal} \mathrm{mol}^{-1}\right)$, even when the basis set superposition error (BSSE) was taken into account. This value runs counter to experimental evidence suggesting a dynamical equilibrium in which $\mathrm{PPh}_{3}$ reversibly binds to 5 (i.e., a thermoneutral process with $\Delta G^{\circ} \approx 0 \mathrm{kcal}$ $\left.\mathrm{mol}^{-1}\right)$. Although dispersion-corrected DFT can predict phosphine-metal binding energies with good accuracy, ${ }^{20}$ in the present example the metal-ligand bond strength appears to be strongly overestimated by the calculations. Of a range of functionals that were tested, B3LYP-D3 performs well for the phosphine binding energy (see Table 2). ${ }^{20 \mathrm{e}}$ However, with this

Table 2. Summary of the Functional Dependence of Phosphine Binding Energies According to $5+\mathrm{PPh}_{3} \leftrightarrows 5 \cdot$ $\mathrm{PPh}_{3}\left(\Delta G_{\text {bind }+\mathrm{BSSE}}\right.$, in $\left.\mathrm{kcal} \mathrm{mol}^{-1}\right)$ as Well as Key Energy Spans for the Overall Reaction Profile in Figure $4^{a}$

$\begin{array}{lcccc}\text { functional } & \Delta G_{\text {bind }+ \text { BSSE }} & \Delta G(1) & \Delta G(2) & \Delta G(2)^{\prime} \\ \text { BP86-D3 } & -13.6 & 22.2 & 22.6 & 14.6 \\ \text { B97-D3 } & -7.6 & 21.1 & 26.4 & 18.5 \\ \text { B3LYP-D3 } & +0.1 & 25.6 & 29.9 & 21.5 \\ \text { M06 } & +8.6 & 24.9 & 33.7 & 24.4\end{array}$

${ }^{a}$ See Figure 4 for the definition of $\left.\Delta G(1), \Delta G(2) \Delta G(2)^{\prime}\right)$.

approach the overall barriers linking 4 to 3 and 5 to 3 are in excess of $25 \mathrm{kcal} \mathrm{mol}^{-1}$, rather too high for these room temperature processes. It seems that no single functional can provide balanced energetics for the various ligand binding and bond activation steps in this system. Nonetheless, our conclusions regarding the mechanism for the convergent formation of $\mathbf{3}$ from $\mathbf{4}$ and $\mathbf{5}$, respectively, obtained with the B97-D3/BS2//BP86/BS1 protocol are qualitatively in good agreement with the experimental observations.

It is plausible that dissociation of $\mathrm{PPh}_{3}$ from $5 \cdot \mathrm{PPh}_{3}$ must occur prior to $\mathrm{C}-\mathrm{H}$ bond activation to give 6 . Indeed, a stepwise relaxed scan of the $\mathrm{Rh} \cdots \mathrm{C}^{\mathrm{a}}$ distance in $5 \cdot \mathrm{PPh}_{3}$ induces dissociation of one $\mathrm{PPh}_{3}$ ligand, restoring the square-planar geometry of 5 before accessing TS(5-6). The computed intrinsic reaction coordinate clearly confirms that $\operatorname{TS}(5-6)$ connects $\mathbf{6}$ to $\mathbf{5}$ providing support for $\mathbf{5}$ as an intermediate along the reaction profile. 


\section{CONCLUSIONS}

$\left[\mathrm{RhH}\left(\mathrm{PPh}_{3}\right)_{4}\right]$ reacts with both the POP ketone (1) and POP alcohol (2) proligands to produce $\alpha$-hydroxylalkyl (3) through convergent pathways. A number of key intermediates for both branches of this reactivity were either isolated and fully characterized or characterized in situ by NMR spectroscopy. In particular, reaction with 1 gives intermediate 4, a rare example of a trapped $\eta^{2}$-ketone hydrido complex that subsequently undergoes insertion. With 2 the reaction proceeds via $\mathrm{C}-\mathrm{H}$ activation geminal to the hydroxyl group. Independent synthesis of hydrido chloride complex 7 provided evidence of the feasibility of this novel $\mathrm{C}-\mathrm{H}$ activation.

The underlying mechanisms were further validated by DFT calculations. These show that the formation of 3 from 4 involves initial mer-fac-isomerization of the ligand followed by rate-limiting insertion. For the generation of 3 from POP alcohol precursor 5 , the initial $\mathrm{C}-\mathrm{H}$ oxidative addition is ratelimiting, and this process is facilitated by the presence of $\mathrm{PPh}_{3}$ which $\mathrm{H}$-bonds to the $\mathrm{C}(\mathrm{H}) \mathrm{OH}$ moiety of the ligand.

The observed reactivity supports $\alpha$-hydroxylalkyl complexes as competent intermediates in ketone hydrogenation catalyzed by rhodium hydrides and suggests that $\mathbf{1}$ and $\mathbf{2}$ may be "noninnocent" ligands in reported hydrogenation catalyst systems. This work demonstrates a new strategy via ketone insertion to access $\mathrm{PC}_{\mathrm{sp} 3} \mathrm{P}$ pincer complexes for metals that disfavor $\mathrm{C}-\mathrm{H}$ activation. Additionally, the demonstration of $\mathrm{C}-\mathrm{H}$ activation of a geminal hydroxyl position provides insight into the selective $\mathrm{C}-\mathrm{H}$ activation in the presence of an alcohol functionality. Ongoing research is being undertaken to determine the reactivity of compound 3 and its analogues, particularly in regards to developing new synthetic routes to $\mathrm{PC}_{\mathrm{sp} 3} \mathrm{P}$ and $\mathrm{PC}_{\mathrm{sp} 2} \mathrm{P}$ pincer complexes and their potential in catalysis.

\section{EXPERIMENTAL SECTION}

General Information. All manipulations were carried out under nitrogen using a glovebox and/or Schlenk techniques. All reactions were performed in glassware that was oven-dried for at least $12 \mathrm{~h}$. Benzene was distilled over sodium and benzophenone under a nitrogen atmosphere and stored over $4 \AA$ molecular sieves prior to use. Diethyl ether and $n$-hexane were dried over activated alumina using an LC Technology Solution Inc. SP-1 Solvent Purification System and deoxygenated prior to use. $\mathrm{C}_{6} \mathrm{D}_{6}$ used was stirred over $\mathrm{CaH}_{2}$ at room temperature under a nitrogen atmosphere overnight prior to distillation under reduced pressure and storage over $4 \AA$ molecular sieves. Toluene- $d_{8}$ was deoxygenated and stored over $4 \AA$ molecular sieves prior to use. $\left[\mathrm{RhH}\left(\mathrm{PPh}_{3}\right)_{4}\right]$ and ligands $\mathbf{1}$ and $\mathbf{2}$ were prepared according to reported methods. ${ }^{21}$

NMR spectroscopy data were obtained using Bruker AV-300, AV400, and AV-500 spectrometers. HRMS (ESI-TOF) spectra were obtained using an Agilent Technologies 6230 TOF LC/MS. IR spectroscopy data were obtained using Bruker ALPHA FTIR spectrometers.

Synthesis of Complex 3. $1(10 \mathrm{mg}, 0.018 \mathrm{mmol})$ and $\left[\mathrm{RhH}\left(\mathrm{PPh}_{3}\right)_{4}\right](21 \mathrm{mg}, 0.018 \mathrm{mmol})$ were added to a NMR tube under $\mathrm{N}_{2}$ atmosphere. The components were dissolved in $\mathrm{C}_{6} \mathrm{D}_{6}(0.6$ $\mathrm{mL})$ to form an orange solution immediately, which turned green overnight. NMR analyses showed the reaction to be virtually quantitative in the formation of complex 3. ${ }^{1} \mathrm{H}$ NMR $(300 \mathrm{MHz}$, $\left.\mathrm{C}_{6} \mathrm{D}_{6}\right)=\delta_{\mathrm{H}} 3.15\left(\mathrm{~d},{ }^{4} J_{\mathrm{PH}}=3.5 \mathrm{~Hz}, 1 \mathrm{H}, \mathrm{OH}\right), 6.68-7.09(\mathrm{~m}, 27 \mathrm{H}, \mathrm{Ar}-$ $H), 7.23-7.47(\mathrm{~m}, 15 \mathrm{H}, \mathrm{Ar}-\mathrm{H}), 7.59\left(\mathrm{~d},{ }^{3} J_{\mathrm{HH}}=7.8 \mathrm{~Hz}, 2 \mathrm{H}, \mathrm{Ar}-\mathrm{H}\right)$. ${ }^{13} \mathrm{C}\left\{{ }^{1} \mathrm{H}\right\} \mathrm{NMR}\left(126 \mathrm{MHz}, \mathrm{C}_{6} \mathrm{D}_{6}\right)=\delta_{\mathrm{C}} 162.7\left(\mathrm{t}, J_{\mathrm{PC}}=18.5 \mathrm{~Hz}\right), 145.0$ $\left(\mathrm{dd}, J_{\mathrm{PC}}=19 \mathrm{~Hz}, 8.5 \mathrm{~Hz}\right), 144.6\left(\mathrm{~d}, J_{\mathrm{PC}}=25.3 \mathrm{~Hz}\right), 140.0\left(\mathrm{~d}, J_{\mathrm{PC}}=\right.$ $25.2 \mathrm{~Hz}), 138.9\left(\mathrm{~d}, J_{\mathrm{PC}}=44.2 \mathrm{~Hz}\right), 138.7\left(\mathrm{~d}, J_{\mathrm{PC}}=25.7 \mathrm{~Hz}\right), 137.3(\mathrm{t}$, $\left.J_{\mathrm{PC}}=16.0 \mathrm{~Hz}\right), 135.1(\mathrm{~s}), 134.3\left(\mathrm{t}, J_{\mathrm{PC}}=11.0 \mathrm{~Hz}\right), 133.8\left(\mathrm{q}, J_{\mathrm{PC}}=6.9\right.$
$\mathrm{Hz}), 131.0(\mathrm{~s}), 128.5\left(\mathrm{t}, J_{\mathrm{CP}}=5.6 \mathrm{~Hz}\right), 127.6\left(\mathrm{~d}, J_{\mathrm{CP}}=8.9 \mathrm{~Hz}\right), 126.5$ (s) $106.1\left(\mathrm{ddt},{ }^{2} J_{\mathrm{PC}}=73.5(\mathrm{~d}), 4.8(\mathrm{t}) \mathrm{Hz},{ }^{1} J_{\mathrm{RhC}}=25.2 \mathrm{~Hz}\right) .{ }^{31} \mathrm{P}\left\{{ }^{1} \mathrm{H}\right\}$ $\operatorname{NMR}\left(162 \mathrm{MHz}, \mathrm{C}_{6} \mathrm{D}_{6}\right)=\delta_{\mathrm{P}} 37.5\left(\mathrm{dt},{ }^{1} J_{\mathrm{RhP}}=120.4(\mathrm{~d}),{ }^{2} J_{\mathrm{PP}}=28.3\right.$ (t) Hz, 1P), $43.3\left(\mathrm{dd},{ }^{1} J_{\mathrm{RhP}}=189.2(\mathrm{~d}),{ }^{2} J_{\mathrm{PP}}=28.3\right.$ (d) Hz, 2P). HRMS (ESI-TOF) $m / z:[\mathrm{M}-\mathrm{H}]^{+}$Calcd for $\mathrm{C}_{55} \mathrm{H}_{43} \mathrm{OP}_{3} \mathrm{Rh}$ 915.1582; Found 915.1546; $[\mathrm{M}-\mathrm{OH}]^{+}$Calcd for $\mathrm{C}_{55} \mathrm{H}_{43} \mathrm{P}_{3} \mathrm{Rh}$ 899.1633; Found 899.1595 .

Synthesis of Complex 4. Method A. Benzene $(5 \mathrm{~mL})$ was added to a mixture of $1(55.1 \mathrm{mg}, 0.100 \mathrm{mmol})$ and $\left[\mathrm{RhH}\left(\mathrm{PPh}_{3}\right)_{4}\right](115.3$ $\mathrm{mg}, 0.100 \mathrm{mmol}$ ), and the resultant orange solution stirred at room temperature for $30 \mathrm{~min}$, after which the solution was filtered. The filtrate was evaporated to give an orange residue and $n$-hexane ( 15 $\mathrm{mL}$ ) was added. After trituration of the mixture for $5 \mathrm{~min}$, the solid was filtered and washed with diethyl ether $(2 \times 2 \mathrm{~mL})$ and then $n$ hexane $(5 \times 10 \mathrm{~mL})$. After drying in vacuo, the product was isolated as an orange solid $(64 \mathrm{mg}, 70 \%)$.

Method B. $\mathrm{Li}\left[\mathrm{N}\left(\mathrm{SiMe}_{3}\right)_{2}\right](11.7 \mathrm{mg}, 0.07 \mathrm{mmol})$ was added to solution of $7(66.7 \mathrm{mg}, 0.07 \mathrm{mmol})$ in $\mathrm{C}_{6} \mathrm{H}_{6}(5 \mathrm{~mL})$ at room temperature and stirred for $15 \mathrm{~min}$. The solution was rapidly evaporated under vacuum, and then diethyl ether $(5 \mathrm{~mL})$ was added. After trituration of the mixture for $5 \mathrm{~min}$, the solid was filtered and washed with diethyl ether $(2 \mathrm{~mL})$ and then $n$-hexane $(2 \times 10 \mathrm{~mL})$. After drying in vacuo, product 4 was isolated as an orange solid (35 mg, 55\%). ${ }^{1} \mathrm{H}$ NMR $\left(500 \mathrm{MHz}, \mathrm{C}_{6} \mathrm{D}_{6}\right)=\delta_{\mathrm{H}}-13.27\left(\mathrm{ddt},{ }^{1} J_{\mathrm{RhH}}=21.2\right.$ (d), $\left.{ }^{2} J_{\mathrm{PH}}=10.3(\mathrm{~d}),{ }^{2} J_{\mathrm{PH}}=4.2(\mathrm{~d}) \mathrm{Hz}, 1 \mathrm{H}, \mathrm{Rh}-\mathrm{H}\right), 6.64-7.04(\mathrm{~m}$, 31H, Ar- H), 7.48-7.55 (m, 6H, Ar-H), 7.59-7.67 (m, 4H, Ar-H), 8.05 $\left(\mathrm{d},{ }^{3} J_{\mathrm{H}-\mathrm{H}}=8.0 \mathrm{~Hz}, 2 \mathrm{H}, \mathrm{Ar}-\mathrm{H}\right) .{ }^{13} \mathrm{C}\left\{{ }^{1} \mathrm{H}\right\}$ NMR $\left(126 \mathrm{MHz}, \mathrm{C}_{6} \mathrm{D}_{6}\right)=\delta_{\mathrm{C}}$ $156.8\left(\mathrm{t}, J_{\mathrm{PC}}=13.0 \mathrm{~Hz}\right), 137.8\left(\mathrm{dd},{ }^{1} J_{\mathrm{RhC}}=23.7(\mathrm{~d}),{ }^{2} J_{\mathrm{PC}}=9.2(\mathrm{~d})\right.$ $\mathrm{Hz}), 137.1(\mathrm{~m}), 134.7\left(\mathrm{~d}, J_{\mathrm{PC}}=13.5 \mathrm{~Hz}\right), 133.8(\mathrm{~s}), 133.4\left(\mathrm{dt}, J_{\mathrm{PC}}=\right.$ $20.0(\mathrm{~d}), 6.9(\mathrm{t}) \mathrm{Hz}), 129.1(\mathrm{~s}), 128.9(\mathrm{~s}), 128.4(\mathrm{~s}), 128.2\left(\mathrm{~d}, J_{\mathrm{PC}}=\right.$ $28.7 \mathrm{~Hz}), 127.4\left(\mathrm{~d}, J_{\mathrm{PC}}=8.3 \mathrm{~Hz}\right), 127.3\left(\mathrm{t}, J_{\mathrm{PC}}=4.1 \mathrm{~Hz}\right), 126.0(\mathrm{~m})$, $125.4(\mathrm{~s}) .{ }^{31} \mathrm{P}\left\{{ }^{1} \mathrm{H}\right\}$ NMR $\left(162 \mathrm{MHz}, \mathrm{C}_{6} \mathrm{D}_{6}\right)=\delta_{\mathrm{P}} 31.0\left(\mathrm{dt},{ }^{1} J_{\mathrm{RhP}}=\right.$ 108.9 (d), $\left.{ }^{2} J_{\mathrm{PP}}=10.1(\mathrm{t}) \mathrm{Hz}, 1 \mathrm{P}\right), 40.4\left(\mathrm{dd},{ }^{1} J_{\mathrm{RhP}}=130.6(\mathrm{~d}),{ }^{2} J_{\mathrm{PP}}=\right.$ 10.1 (d) Hz, 2P). IR (nujol mull): $1969[\nu(\mathrm{Rh}-\mathrm{H})] \mathrm{cm}^{-1}$; HRMS (ESI-TOF) $m / z$ : $[\mathrm{M}+\mathrm{H}]^{+}$Calcd for $\mathrm{C}_{55} \mathrm{H}_{45} \mathrm{OP}_{3} \mathrm{Rh}$ 917.1738; Found 917.1736.

Synthesis of Complex 7. Benzene $(2 \mathrm{~mL})$ was added to a mixture of $2(27.6 \mathrm{mg}, 0.05 \mathrm{mmol})$ and $\left[\mathrm{RhCl}\left(\mathrm{PPh}_{3}\right)(\mathrm{COD})\right](25.4 \mathrm{mg}, 0.05$ $\mathrm{mmol}$ ), and the resultant solution was stirred at room temperature for $1 \mathrm{~h}$. The solution was concentrated under vacuum to give a residue, and then $n$-hexane $(5 \mathrm{~mL})$ was added to produce a precipitate. The solid was filtered and washed with $n$-hexane $(3 \times 5 \mathrm{~mL})$. After drying in vacuo, the product was isolated as yellow-brown solid (31 mg, 65\%). ${ }^{1} \mathrm{H}$ NMR $\left(500 \mathrm{MHz}, \mathrm{C}_{6} \mathrm{D}_{6}\right)=\delta_{\mathrm{H}}-16.22\left(1 \mathrm{H}, \mathrm{dtd},{ }^{1} J_{\mathrm{RhH}}=22.1 \mathrm{~Hz}\right.$ (d), $\left.{ }^{2} J_{\mathrm{PH}}=14.3 \mathrm{~Hz}(\mathrm{t}),{ }^{2} J_{\mathrm{PH}}=9.2 \mathrm{~Hz}(\mathrm{~d}), \mathrm{Rh}-H\right), 7.57\left(1 \mathrm{H}, \mathrm{d}, J_{\mathrm{PH}}=\right.$ $7.5 \mathrm{~Hz}, \mathrm{OH}), 8.2-6.6(43 \mathrm{H}, \mathrm{m}, \mathrm{Ar}-\mathrm{H}) .{ }^{13} \mathrm{C}\left\{{ }^{1} \mathrm{H}\right\}$ NMR $(126 \mathrm{MHz}$, $\left.\mathrm{C}_{6} \mathrm{D}_{6}\right)=\delta_{\mathrm{C}} 163.9\left(\mathrm{t}, J_{\mathrm{PC}}=15 \mathrm{~Hz}\right), 141.9\left(\mathrm{t}, J_{\mathrm{PC}}=25 \mathrm{~Hz}\right), 136.4\left(\mathrm{t}, J_{\mathrm{PC}}\right.$ $=24 \mathrm{~Hz}), 135.1(\mathrm{~s}(\mathrm{br})), 134.4\left(\mathrm{t}, J_{\mathrm{PC}}=5.6 \mathrm{~Hz}\right), 133.6\left(\mathrm{t}, J_{\mathrm{PC}}=5.6\right.$ $\mathrm{Hz}), 133.0(\mathrm{~s}), 130.0(\mathrm{~s}(\mathrm{br})), 129.2(\mathrm{~s}), 129.1(\mathrm{~s}), 128.9(\mathrm{~s}), 128.3$ (s), $127.3\left(\mathrm{~d}, J_{\mathrm{PC}}=8.4 \mathrm{~Hz}\right), 124.4(\mathrm{~s}(\mathrm{br})), 99.4\left(\mathrm{dd}, J_{\mathrm{PC}}=94.1 \mathrm{~Hz}\right.$, $\left.J_{\mathrm{RhC}}=20.8 \mathrm{~Hz}\right) \cdot{ }^{31} \mathrm{P}\left\{{ }^{1} \mathrm{H}\right\} \mathrm{NMR}\left(202 \mathrm{MHz}, \mathrm{C}_{6} \mathrm{D}_{6}\right)=\delta 39.7\left(\mathrm{dd}, J_{\mathrm{RhP}}=\right.$ $\left.120.0 \mathrm{~Hz}, J_{\mathrm{PP}}=24.0 \mathrm{~Hz}, 2 \mathrm{P}\right), 23.7\left(\mathrm{dt}, J_{\mathrm{RhP}}=79.0 \mathrm{~Hz}, J_{\mathrm{PP}}=24.0 \mathrm{~Hz}, 1\right.$ P). IR (nujol mull): $2079[\nu(\mathrm{Rh}-\mathrm{H})], 3303[\nu(\mathrm{O}-\mathrm{H})] \mathrm{cm}^{-1}$. HRMS (ESI-TOF) $\mathrm{m} / z$ : $[\mathrm{M}-\text { Hydride }]^{+}$Calcd for $\mathrm{C}_{55} \mathrm{H}_{44} \mathrm{ClOP}_{3} \mathrm{Rh}$ 951.1349; Found 951.1335; $[\mathrm{M}-\mathrm{Cl}]^{+}$Calcd for $\mathrm{C}_{55} \mathrm{H}_{45} \mathrm{OP}_{3} \mathrm{Rh}$ 917.1738; Found 917.1703.

In Situ Characterization of Complex $5.2(10 \mathrm{mg}, 0.018 \mathrm{mmol})$ and $\left[\mathrm{RhH}\left(\mathrm{PPh}_{3}\right)_{4}\right](21 \mathrm{mg}, 0.018 \mathrm{mmol})$ were added into a NMR tube under $\mathrm{N}_{2}$ atmosphere. The components were dissolved in $\mathrm{C}_{6} \mathrm{D}_{6}$ $(0.6 \mathrm{~mL})$ and then analyzed soon after. The NMR spectroscopic data were obtained at $280 \mathrm{~K}$ to reduce the rate of conversion from intermediate 5 to complex $3 .{ }^{1} \mathrm{H}$ NMR $\left(500 \mathrm{MHz}, \mathrm{C}_{6} \mathrm{D}_{6}\right)=\delta_{\mathrm{H}}-8.58$ $\left(1 \mathrm{H}, \mathrm{d}(\mathrm{br}),{ }^{2} J_{\mathrm{PH}}=90 \mathrm{~Hz}, \mathrm{Rh}-H\right), 1.39\left(1 \mathrm{H}, \mathrm{d},{ }^{3} J_{\mathrm{HH}}=3.3 \mathrm{~Hz}, \mathrm{OH}\right)$, 8.0-6.2 (43 H, m, Ar- $\mathrm{H}), 9.87(1 \mathrm{H}, \mathrm{s}(\mathrm{br}), \mathrm{C}(\mathrm{OH})-\mathrm{H}) .{ }^{1} \mathrm{H}-{ }^{1} \mathrm{H}$ COSY NMR shows strong correlation between signals at $\delta_{\mathrm{H}} 9.87$ and 1.39. The doublet at $\delta_{\mathrm{H}} 1.39$ is not resolved upon broadband ${ }^{31} \mathrm{P}$ decoupling. Selected ${ }^{13} \mathrm{C}$ NMR data (from HMBC/HSQC) $=\delta_{\mathrm{C}} 69.3$ (C), $147.4(\mathrm{C}) .{ }^{31} \mathrm{P}\left\{{ }^{1} \mathrm{H}\right\}$ NMR $\left(202 \mathrm{MHz}, \mathrm{C}_{6} \mathrm{D}_{6}\right)=\delta_{\mathrm{P}} 31.0(\mathrm{~d}(\mathrm{br})$, $\left.{ }^{1} J_{\mathrm{RhP}}=131 \mathrm{~Hz}\right), 34.3\left(\mathrm{~d}(\mathrm{br}),{ }^{1} J_{\mathrm{RhP}}=170 \mathrm{~Hz}\right)$. 
In Situ Characterization of Complex 6. To a sample of 3 prepared from 1 and $\left[\mathrm{RhH}\left(\mathrm{PPh}_{3}\right)_{4}\right]$ in toluene- $d_{8}(0.6 \mathrm{~mL})$ as described above was applied a pressure of hydrogen gas $(4 \mathrm{~atm})$. The sample was then analyzed using VT-NMR spectroscopic experiments. Selected NMR spectroscopic data for 6 at $233 \mathrm{~K}:{ }^{1} \mathrm{H}$ NMR ( $500 \mathrm{MHz}$, $\left.\mathrm{C}_{6} \mathrm{D}_{6}\right)=\delta_{\mathrm{H}}-6.8\left(2 \mathrm{H}, \mathrm{d}(\mathrm{br}),{ }^{2} J_{\mathrm{PH}}=140 \mathrm{~Hz}, \mathrm{Rh}-H\right), 4.25(1 \mathrm{H}, \mathrm{d}$, $\left.{ }^{4} J_{\mathrm{PH}}=4.4 \mathrm{~Hz}, \mathrm{OH}\right) \cdot{ }^{13} \mathrm{C} \mathrm{NMR}$ data $($ from HMBC$)=\delta_{\mathrm{C}} 95.8(1 \mathrm{C}, \mathrm{dd}$, $\left.{ }^{2} J_{\mathrm{PC}}=95.2 \mathrm{~Hz},{ }^{1} J_{\mathrm{RhC}}=28.6 \mathrm{~Hz}, \mathrm{Rh}-\mathrm{C}-\mathrm{OH}\right) \cdot{ }^{31} \mathrm{P}\left\{{ }^{1} \mathrm{H}\right\} \mathrm{NMR}(202$ $\left.\mathrm{MHz}, \mathrm{C}_{6} \mathrm{D}_{6}\right)=\delta_{\mathrm{P}} 45.6\left(\mathrm{~d}(\mathrm{br}),{ }^{1} J_{\mathrm{RhP}}=86.5 \mathrm{~Hz}\right), 41.7\left(\mathrm{dt},{ }^{1} J_{\mathrm{RhP}}=84.5\right.$ $\left.\mathrm{Hz},{ }^{2} J_{\mathrm{PP}}=14.9 \mathrm{~Hz}\right)$.

Preparation of Deuterium-Labeled Ligand 2a. A 1:1 mixture of $\mathrm{D}_{2} \mathrm{O} / \mathrm{THF}$ was added to 2 followed by evaporation to dryness. Approximately $81 \%$ deuteration of the hydroxyl position at $2.25 \mathrm{ppm}$ was determined by ${ }^{1} \mathrm{H}$ NMR spectroscopy. ${ }^{1} \mathrm{H}$ NMR $(400 \mathrm{MHz}$, $\left.\mathrm{C}_{6} \mathrm{D}_{6}\right)=\delta_{\mathrm{H}} 6.89(\mathrm{td}, J=7.5,1.4 \mathrm{~Hz}, 2 \mathrm{H}, \mathrm{Ar}-\mathrm{H}), 6.94-7.06(\mathrm{~m}, 14 \mathrm{H}$, Ar- $H$ ), 7.19-7.24 (m, 2H, Ar-H), 7.27-7.37 (m, 8H, Ar-H), 7.50$7.56(\mathrm{~m}, 2 \mathrm{H}, \operatorname{Ar}-H), 7.76(\mathrm{t}, J=6.2 \mathrm{~Hz}, 1 \mathrm{H}, \mathrm{C}(\mathrm{OH})-H) .{ }^{31} \mathrm{P}\left\{{ }^{1} \mathrm{H}\right\}$ $\operatorname{NMR}\left(162 \mathrm{MHz}, \mathrm{C}_{6} \mathrm{D}_{6}\right)=\delta_{\mathrm{P}}-17.3(\mathrm{~s}, 2 \mathrm{P})$.

Preparation of Deuterium-Labeled Ligand 2b. Part A. (2Bromophenyl)diphenylphosphene $(2.00 \mathrm{~g}, 5.9 \mathrm{mmol})$ was dissolved in diethyl ether $(25 \mathrm{~mL})$. The solution is then treated dropwise with $n$ $\mathrm{BuLi}$ in hexane $(6 \mathrm{~mL}, 1.6 \mathrm{M}, 9.6 \mathrm{mmol})$ at $-78{ }^{\circ} \mathrm{C}$ and stirred for 30 min. Dimethylformamide- $d_{7}(3 \mathrm{~mL}, 38.6 \mathrm{mmol})$ was added thereafter at $-78{ }^{\circ} \mathrm{C}$. The mixture was then allowed to come to room temperature and was stirred overnight. Dilute aqueous $\mathrm{HCl}$ solution $(20 \mathrm{~mL})$ was added, and then the aldehyde product was extracted using DCM $(3 \times 30 \mathrm{~mL})$. The combined extractions were dried with $\mathrm{Na}_{2} \mathrm{SO}_{4}$ and then evaporated. The crude product was then recrystallized using methanol to give deutero 2-(diphenylphosphino)benzaldehyde (0.901 g, 52\%).

Part B. (2-Bromophenyl)diphenylphosphine $(0.423 \mathrm{~g}, 1.24 \mathrm{mmol})$ was dissolved in diethyl ether $(10 \mathrm{~mL})$ and treated with $n$-BuLi $(2.9$ $\mathrm{mL}, 1.6 \mathrm{M}, 1.78 \mathrm{mmol})$ at $0{ }^{\circ} \mathrm{C}$. The reaction mixture was stirred for $30 \mathrm{~min}$; thereafter, deutero 2-(diphenylphosphino)benzaldehyde $(0.519 \mathrm{~g}, 1.78 \mathrm{mmol})$ was added. The reaction mixture was then stirred for an additional hour. The mixture is then allowed to come to room temperature, and degassed dilute aqueous $\mathrm{HCl}$ solution was added. Then, the product was extracted with diethyl ether $(3 \times 20$ $\mathrm{mL})$. The solvent was removed under vacuum and the crude product was recrystallized using methanol to give ligand $2 \mathbf{b}$ as a white solid $(0.136 \mathrm{~g}, 20 \%) .{ }^{1} \mathrm{H}$ NMR $\left(400 \mathrm{MHz}, \mathrm{C}_{6} \mathrm{D}_{6}\right)=\delta_{\mathrm{H}} 2.25(\mathrm{t}, J=1.4 \mathrm{~Hz}$, $1 \mathrm{H}, \mathrm{OH}), 6.89(\mathrm{td}, J=7.5,1.4 \mathrm{~Hz}, 2 \mathrm{H}, \mathrm{Ar}-\mathrm{H}), 6.94-7.09$ (m, $14 \mathrm{H}, \mathrm{Ar}-$ $H)$, 7.18-7.24 (m, 2H, Ar-H), 7.26-7.37 (m, 8H, Ar-H), 7.49-7.56 $(\mathrm{m}, 2 \mathrm{H}, \mathrm{Ar}-\mathrm{H}) .{ }^{31} \mathrm{P}\left\{{ }^{1} \mathrm{H}\right\} \operatorname{NMR}\left(162 \mathrm{MHz}, \mathrm{C}_{6} \mathrm{D}_{6}\right)=\delta_{\mathrm{P}}-17.3(\mathrm{~s}, 2 \mathrm{P})$.

\section{ASSOCIATED CONTENT}

\section{S Supporting Information}

The Supporting Information is available free of charge on the ACS Publications website at DOI: 10.1021/acs.organomet.7b00158.

Experimental methods, formation and isolation details, NMR monitoring details and spectra, HRMS spectra, Xray crystallography data, and DFT calculations (PDF) Crystallographic information files for 3, 4, and 7 (CIF) Cartesian coordinates for 4 (XYZ)

\section{AUTHOR INFORMATION}

\section{Corresponding Authors}

*E-mail: t.kraemer@hw.ac.uk.

*E-mail: rowan.young@nus.edu.sg.

\section{ORCID $\odot$}

Simon Sung: 0000-0002-7864-7694

Stuart A. Macgregor: 0000-0003-3454-6776

Tobias Krämer: 0000-0001-5842-9553

Rowan D. Young: 0000-0001-7437-8944

\section{Notes}

The authors declare no competing financial interest.

\section{ACKNOWLEDGMENTS}

We thank the National University of Singapore and the Singapore Ministry of Education for financial support (WBS R143-000-586-112 and R-143-000-666-114) and Heriot-Watt University for the award of a James Watt Scholarship.

\section{REFERENCES}

(1) (a) Birch, A. J.; Williamson, D. H. In Organic Reactions; John Wiley \& Sons, Inc.: Hoboken, NJ, 2011. (b) de Vries, J. G.; Elsevier, C. J. The Handbook of Homogeneous Hydrogenation; Wiley-VCH: Weinheim, 2007.

(2) (a) Schrock, R. R.; Osborn, J. A. J. Chem. Soc. D 1970, 567. (b) Malacea, R.; Poli, R.; Manoury, E. Coord. Chem. Rev. 2010, 254, 729. (c) Samec, J. S. M.; Bäckvall, J.-E.; Andersson, P. G.; Brandt, P. Chem. Soc. Rev. 2006, 35, 237. (d) Clapham, S. E.; Hadzovic, A.; Morris, R. H. Coord. Chem. Rev. 2004, 248, 2201. (e) Gregorio, G.; Pregaglia, G.; Ugo, R. Inorg. Chim. Acta 1969, 3, 89. (f) Abdur-Rashid, K.; Clapham, S. E.; Hadzovic, A.; Harvey, J. N.; Lough, A. J.; Morris, R. H. J. Am. Chem. Soc. 2002, 124, 15104. (g) Wigfield, D. C. Tetrahedron 1979, 35, 449.

(3) Related systems that partake in ligand-assisted ionic hydrogenations typically rely upon the ligand to deliver a protic hydrogen, while the metal hydride transfers to the electrophilic carbonyl position (i.e., the metal-hydride also acts as a nucleophile as in route A). See (a) Bullock, R. M. Chem. - Eur. J. 2004, 10 (10), 2366. (b) Clapham, S. E.; Hadzovic, A.; Morris, R. H. Coord. Chem. Rev. 2004, 248 (21-24), 2201. (c) Wang, D.; Astruc, D. Chem. Rev. 2015, 115 (13), 6621.

(4) (a) Simpson, M. C.; Cole-Hamilton, D. J. Coord. Chem. Rev. 1996, 155, 163. (b) MacDougall, J. K.; Simpson, M. C.; Green, M. J.; Cole-Hamilton, D. J. J. J. Chem. Soc., Dalton Trans. 1996, 1161. (c) Sola, M.; Ziegler, T. Organometallics 1996, 15, 2611. (d) Cheliatsidou, P.; White, D. F. S.; Slawin, A. M. Z.; ColeHamilton, D. J. Dalton Trans. 2008, 2389. (e) MacDougall, J. K.; Simpson, M. C.; Green, M. J.; Cole-Hamilton, D. J. J. J. Chem. Soc., Dalton Trans. 1996, 1161. (f) Fahey, D. R. J. Am. Chem. Soc. 1981, 103, 136. (g) Milstein, D. J. Am. Chem. Soc. 1986, 108, 3525.

(5) For examples, see (a) Peterson, E.; Khalimon, A. Y.; Simionescu, R.; Kuzmina, L. G.; Howard, J. A. K.; Nikonov, G. I. J. Am. Chem. Soc. 2009, 131, 908. (b) Sieffert, N.; Bühl, M. J. Am. Chem. Soc. 2010, 132, 8056. (c) Bosson, J.; Poater, A.; Cavallo, L.; Nolan, S. P. J. Am. Chem. Soc. 2010, 132, 13146. (d) Khalimon, A. Y.; Ignatov, S. K.; Simionescu, R; Kuzmina, L. G.; Howard, J. A. K.; Nikonov, G. I. Inorg. Chem. 2012, 51, 754. (e) Wang, W.; Gu, P.; Wang, Y.; Wei, H. Organometallics 2014, 33, 847. (f) Iron, M. A.; Sundermann, A.; Martin, J. M. L. J. Am. Chem. Soc. 2003, 125, 11430.

(6) (a) Pruett, R. L. Ann. N. Y. Acad. Sci. 1977, 295, 239. (b) Feder, H. M.; Rathke, J. W. Ann. N. Y. Acad. Sci. 1980, 333, 45. (c) Fahey, D. R. J. Am. Chem. Soc. 1981, 103, 136. (d) Bradley, J. S. J. Am. Chem. Soc. 1979, 101, 7419. (e) Dombek, B. D. J. Am. Chem. Soc. 1980, 102, 6855. (f) Keim, W.; Berger, M.; Schlupp, J. J. Catal. 1980, 61, 359. (g) Daroda, R. J.; Blackborow, J. R.; Wilkinson, G. J. Chem. Soc., Chem. Commun. 1980, 1098. (h) Daroda, R. J.; Blackborow, J. R.; Wilkinson, G. J. Chem. Soc., Chem. Commun. 1980, 0, 1101. (i) Paxson, T. E.; Reilly, C. A.; Holecek, D. R. J. Chem. Soc., Chem. Commun. 1981, 618. (j) Knifton, J. F. J. Chem. Soc., Chem. Commun. 1981, 188. (k) Backvall, J. E.; Akermark, B.; Ljunggren, S. O. J. Am. Chem. Soc. 1979, 101, 2411. (1) Roth, J. A.; Orchin, M. J. Organomet. Chem. 1979, 172, C27. (m) Sisak, A.; Sámpár-Szerencsés, E.; Galamb, V.; Németh, L.; Ungváry, F.; Pályi, G. Organometallics 1989, 8, 1096.

(7) (a) Vaughn, G. D.; Gladysz, J. A. J. Am. Chem. Soc. 1981, 103 (18), 5608. (b) Garralda, M. A.; Hernández, R.; Ibarlucea, L.; Pinilla, E.; Torres, M. R.; Zarandona, M. Organometallics 2007, 26, 1031. (c) Van Voorhees, S. L.; Wayland, B. B. Organometallics 1985, 4, 1887.

(d) Fu, X.; Basickes, L.; Wayland, B. B. Chem. Commun. 2003, 520.

(e) Fu, X.; Wayland, B. B. J. Am. Chem. Soc. 2005, 127, 16460. 
(f) Vaughn, G. D.; Strouse, C. E.; Gladysz, J. A. J. Am. Chem. Soc. 1986, 108, 1462. (g) Vaughn, G. D.; Gladysz, J. A. J. Am. Chem. Soc. 1986, 108, 1473. (h) Brockaart, G.; El Mail, R.; Garralda, M. A.; Hernández, R.; Ibarlucea, L.; Santos, J. I. Inorg. Chim. Acta 2002, 338, 249. (i) El Mail, R.; Garralda, M. A.; Hernández, R.; Ibarlucea, L.; Pinilla, E.; Torres, M. R. Organometallics 2000, 19, 5310.

(8) For current state-of-the-art, see (a) Nguyen, K. D.; Herkommer, D.; Krische, M. J. J. Am. Chem. Soc. 2016, 138, 14210. (b) Geary, L. M.; Glasspoole, B. W.; Kim, M. M.; Krische, M. J. J. Am. Chem. Soc. 2013, 135, 3796. (c) Patman, R. L.; Chaulagain, M. R.; Williams, V. M.; Krische, M. J. J. Am. Chem. Soc. 2009, 131, 2066.

(9) Jing, Q.; Sandoval, C. A.; Wang, Z.; Ding, K. Eur. J. Org. Chem. 2006, 2006, 3606.

(10) Nakamura, Y.; Yoshikai, N.; Ilies, L.; Nakamura, E. Org. Lett. 2012, 14, 3316.

(11) Saes, B. W. H.; Verhoeven, D. G. A.; Lutz, M.; Klein Gebbink, R. J. M.; Moret, M.-E. Organometallics 2015, 34, 2710.

(12) (a) Doyle, L. E.; Piers, W. E.; Borau-Garcia, J. J. Am. Chem. Soc. 2015, 137, 2187. (b) Doyle, L. E.; Piers, W. E.; Borau-Garcia, J.; Sgro, M. J.; Spasyuk, D. M. Chem. Sci. 2016, 7, 921.

(13) For examples, see (a) Bruce, M. I.; Hambley, T. W.; Snow, M. R.; Swincer, A. G. J. Organomet. Chem. 1982, 235, 105. (b) Akkerman, F. A.; Lentz, D. Angew. Chem., Int. Ed. 2007, 46, 4902. (c) Choi, J.-C.; Sarai, S.; Koizumi, T.; Osakada, K.; Yamamoto, T. Organometallics 1998, 17 (10), 2037. (d) Nishihara, Y.; Yoda, C.; Itazaki, M.; Osakada, K. Bull. Chem. Soc. Jpn. 2005, 78, 1469. (d1) Bianchini, C.; Meli, A.; Peruzzini, M.; Vizza, F.; Frediani, P.; Ramirez, J. A. Organometallics 1990, 9, 226. (e) Tejel, C.; Geer, A. M.; Jiménez, S.; López, J. A.; Ciriano, M. A. Organometallics 2012, 31, 2895. (f) Carr, S. W.; Shaw, B. L.; Thornton-Pett, M. J. Chem. Soc., Dalton Trans. 1987, 1763.

(14) (a) van der Boom, M. E.; Zubkov, T.; Shukla, A. D.; Rybtchinski, B.; Shimon, L. J. W.; Rozenberg, H.; Ben-David, Y.; Milstein, D. Angew. Chem., Int. Ed. 2004, 43, 5961. (b) Daugulis, O.; Brookhart, M. Organometallics 2004, 23, 527. (c) Pawley, R. J.; Huertos, M. A.; Lloyd-Jones, G. C.; Weller, A. S.; Willis, M. C. Organometallics 2012, 31, 5650.

(15) (a) Moxham, G. L.; Randell-Sly, H.; Brayshaw, S. K.; Weller, A. S.; Willis, M. C. Chem. - Eur. J. 2008, 14, 8383. (b) Arras, J.; Speth, H.; Mayer, H. A.; Wesemann, L. Organometallics 2015, 34, 3629. (c) Barthes, C.; Lepetit, C.; Canac, Y.; Duhayon, C.; Zargarian, D.; Chauvin, R. Inorg. Chem. 2013, 52, 48. (d) Lepetit, C.; Poater, J.; Alikhani, M. E.; Silvi, B.; Canac, Y.; Contreras-García, J.; Solà, M.; Chauvin, R. Inorg. Chem. 2015, 54, 2960. (e) Lesueur, W.; Solari, E.; Floriani, C.; Chiesi-Villa, A.; Rizzoli, C. Inorg. Chem. 1997, 36, 3354. (f) Logan, J. R.; Piers, W. E.; Borau-Garcia, J.; Spasyuk, D. M. Organometallics 2016, 35, 1279.

(16) Scherer, W.; Dunbar, A. C.; Barquera-Lozada, J. E.; Schmitz, D.; Eickerling, G.; Kratzert, D.; Stalke, D.; Lanza, A.; Macchi, P.; Casati, N. P. M.; Ebad-Allah, J.; Kuntscher, C. Angew. Chem., Int. Ed. 2015, 54, 2505.

(17) Kozuch, S.; Shaik, S. Acc. Chem. Res. 2011, 44, 101.

(18) Zhang, Y.; Lewis, J. C.; Bergman, R. G.; Ellman, J. A.; Oldfield, E. Organometallics 2006, 25, 3515.

(19) Goodman, J.; Grushin, V. V.; Larichev, R. B.; Macgregor, S. A.; Marshall, W. J.; Roe, D. C. J. Am. Chem. Soc. 2010, 132, 12013.

(20) (a) Minenkov, Y.; Occhipinti, G.; Jensen, V. R. J. Phys. Chem. A 2009, 113, 11833. (b) Zhao, Y.; Truhlar, D. G. Org. Lett. 2007, 9, 1967. (c) Sieffert, N.; Bühl, M. Inorg. Chem. 2009, 48, 4622. (d) McMullin, C. L.; Jover, J.; Harvey, J. N.; Fey, N. Dalton Trans. 2010, 39, 10833. (e) Ahlquist, M. S. G.; Norrby, P.-O. Angew. Chem., Int. Ed. 2011, 50, 11794.

(21) (a) Ahmad, N.; Levison, J. J.; Robinson, S. D.; Uttley, M. F.; Wonchoba, E. R.; Parshall, G. W. Inorg. Synth. 1990, 28, 81-83. (b) Jing, Q.; Sandoval, C. A.; Wang, Z.; Ding, K. Eur. J. Org. Chem. 2006, 2006, 3606-3616. (c) Nakamura, Y.; Yoshikai, N.; Ilies, L.; Nakamura, E. Org. Lett. 2012, 14, 3316-3319. 